\title{
POTENSI SOVATELTIDE (IRL-1620) SEBAGAI OBAT NEUROPROTEKTIF MUTAKHIR STROKE ISKEMIK
}

Jonathan Ricardo Hamonangan , Michael Nobel Simanjuntak, Leonardus Yodi Giovanni

Program Studi Kedokteran, Fakultas Kedokteran, Universitas Padjadjaran, Bandung

\begin{abstract}
Stroke is the second leading cause of death in the world. Ischemic stroke occurs in $88 \%$ of cases of stroke, while bleeding stroke occurs in $12 \%$ of cases. In both adults and children, strokes can cause disability and thus affect the productivity of sufferers. However, pharmacological treatment of ischemic stroke is a challenge for the medical world because of the complex pathology of ischemic stroke. As a recent intervention, Sovateltide (IRL1620 / PMZ-1620) is present as a selective, prospective endothelin B receptors (ETBR) agonist with neuroprotective and angiogenetic effects in ischemic stroke. Although still in clinical trials, there are no literature studies that discuss the potential of Sovateltide as a neuroprotective ischemic stroke. As a solution, this literature study aims to determine the potential of Sovateltide as an advanced neuroprotective drug for ischemic stroke. This systematic literature study is the result of analysis and synthesis of various references relevant to topics in Pubmed and Google Scholar, searched using various keywords, and a period of not more than 10 years. Sovateltide is the most selective ETBR agonist that is able to provide neuroprotective effects by increasing proliferation, survival rate, differentiation, neurogenesis, mitochondrial fusion, and nerve cell development. In addition, Sovateltide is also able to increase Vascular Endothelial Growth Factor (VEGF), causing angiogenesis in brain blood vessels that experience occlusion. Based on the study, administering Sovateltide to samples of adult mice and children with middle cerebral arteries occlusion (MCAO) has the potential to be a neuroprotective drug for acute and subacute ischemic stroke. Sovateltide has good potential as an advanced neuroprotective drug for ischemic stroke.
\end{abstract}

Keywords: Sovateltide, IRL-1620, PMZ-1620, ETBR Agonist, Ischemic Stroke

\begin{abstract}
Abstrak
Stroke adalah penyebab kematian tertinggi kedua di dunia. Stroke iskemik terjadi pada $88 \%$ kasus stroke, sedangkan stroke pendarahan terjadi pada $12 \%$ kasus. Baik pada dewasa maupun anak-anak, stroke dapat menyebabkan kecacatan sehingga memengaruhi produktivitas penderita. Namun, pengobatan stroke iskemik secara farmakologis merupakan tantangan bagi dunia kedokteran karena patologi stroke iskemik yang kompleks. Sebagai intervensi mutakhir, Sovateltide (IRL-1620/PMZ-1620) hadir sebagai agonis endothelin B receptors (ETBR) selektif yang prospektif dengan memberikan efek neuroprotektif dan angiogenesis pada stroke iskemik. Meskipun masih dalam uji coba klinis, belum ada studi pustaka yang membahas mengenai potensi Sovateltide sebagai neuroprotektif stroke iskemik. Sebagai solusinya, studi pustaka ini bertujuan untuk mengetahui potensi Sovateltide sebagai obat neuroprotektif mutakhir stroke iskemik. Studi pustaka secara sistematis ini merupakan hasil analisis dan sintesis dari berbagai referensi yang relevan dengan topik di Pubmed dan Google Scholar, dicari menggunakan berbagai kata kunci, dan jangka waktu tidak lebih dari 10 tahun. Sovateltide merupakan agonis ETBR yang paling selektif sehingga mampu memberikan efek neuroprotektif dengan meningkatkan proliferasi, survival rate, diferensiasi, neurogenesis, fusion mitokondria, dan perkembangan sel saraf. Selain itu, Sovateltide juga mampu meningkatkan Vascular Endothelial Growth Factor (VEGF) sehingga menyebabkan angiogenesis pada pembuluh darah otak yang mengalami oklusi. Berdasarkan penelitian, pemberian Sovateltide pada sampel tikus dewasa dan anak- anak dengan middle cerebral arteries occlusion (MCAO) berpotensi menjadi obat neuroprotektif stroke iskemik fase akut dan subakut. Sovateltide memiliki potensi yang baik sebagai obat neuroprotektif mutakhir stroke iskemik.
\end{abstract}

Keywords: Sovateltide, IRL-1620, PMZ-1620, ETBR Agonist, Ischemic Stroke 


\section{PENDAHULUAN}

Stroke adalah penyebab kematian tertinggi kedua di dunia. Di negara-negara berkembang insidensi stroke semakin meningkat pada 15 tahun terakhir jika dibandingkan dengan negara berpendapatan. Berdasarkan Riset Kesehatan Dasar (Riskesdas) tahun 2018, di Indonesia, stroke terjadi pada kelompok usia 55-64 tahun (33,3\%), 65-74 tahun $(22,5 \%), 45-54$ tahun $(21,8 \%), \geq 75$ tahun (11,5\%), 35-44 tahun (6,9\%), 25-34 tahun $(2,8 \%)$, dan 15-24 tahun (1,2\%).

Berdasarkan World Health Organization (WHO), stroke didefinisikan sebagai sindrom klinis berupa defisit neurologis secara lokal dan global yang terjadi secara tiba- tiba, berkembang dengan cepat, berlangsung selama 24 jam atau lebih, dan dapat menyebabkan kematian tanpa adanya penyebab pasti selain penyebab vaskular. Secara garis besar, stroke dapat diklasifikasikan menjadi stroke pendarahan dan stroke iskemik. Stroke iskemik terjadi pada $88 \%$ kasus stroke, sedangkan stroke pendarahan terjadi pada $12 \%$ kasus. Stroke merupakan salah satu penyebab morbiditas dan mortalitas yang tinggi pada dewasa maupun anak-anak. Stroke dapat menyebabkan kecacatan sehingga memengaruhi produktivitas penderitanya.

Fokus penanganan stroke iskemik adalah untuk memperbaiki aliran darah ke otak atau cerebral blood flow (CBF) yang tersumbat dengan cepat, menurunkan angka kematian, dan mencegah terjadinya sumbatan serta kejadian stroke yang berulang. Pengobatan skemik secara farmakologis merupakan tantangan bagi dunia kedokteran karena patologi stroke iskemik yang kompleks. Saat ini, pengobatan farmakologis utama adalah rekanalisasi arteri dengan aktivator plasminogen jaringan rekombinan (rtPA) disertai dengan awitan awal aspirin. Meskipun demikian, mayoritas pasien stroke tidak memenuhi syarat untuk mendapat trombolitik karena penggunaan rtPA memiliki banyak kontraindikasi dan waktu yang terbatas untuk mendapat hasil yang baik (window period).

Golongan obat neuroprotektif merupakan golongan obat yang saat ini sering digunakan untuk menunda terjadinya infark lebih lanjut pada bagian otak yang sudah mengalami iskemia. Salah satu jenis obat golongan neuroprotektif adalah Citicoline. Namun, masih ada penelitian yang menatakan bahwa Citicoline tidak memberikan manfaat dibandingkan dengan pemberian placebo. Pemberian Citicoline dibandingkan dengan rtPA.

Sejak adanya penelitian yang menyatakan bahwa terjadi peningkatan endothelin (ET) pada plasma dan cairan serebrospinal setelah otak mengalami iskemia, penelitian mengenai terapi dengan mengaktivasi ET pada stroke iskemik banyak dilakukan pada tikus. ET merupakan vasoaktif yang mekanisme kerjanya dimediasi oleh endothelin $A$ receptors (ETAR) dan endothelin $\mathrm{B}$ receptors (ETBR). Otak manusia mengandung banyak ETBR yang terletak pada jaringan saraf, astrosit, dan pembuluh darah otak. Reseptor-reseptor ini berperan dalam $\mathrm{CBF}$, migrasi, proliferasi, dan apoptosis sel. ETBR memediasi relaksasi arteri-arteri kecil di otak dan arteriola melalui aktivasi enzim endothelial nitrix oxide synthase.

Penelitian-penelitian sebelumnya sudah membuktikan bahwa ETBR berperan dalam pertahanan hidup dan proliferasi selsel saraf. Berdasarkan penelitian dengan sampel tikus middle cerebral arteries occlusion (MCAO), Sovateltide (IRL-1620 
/ PMZ-1620) merupakan agonis dari ETBR yang paling selektif dan berpotensi menjadi obat neuroprotektif pada stroke iskemik. Sovateltide berperan dalam aktivasi ETBR yang menyebabkan regenerasi saraf dengan menstimulasi Neuronal Progenitor Cells (NPCs), pembentukan sel-sel saraf yang matang, serta berperan dalam peningkatan angiogenesis dan $\mathrm{CBF}$ setelah terjadi stroke iskemik. Meskipun saat ini Sovateltide masih dalam uji coba klinis, belum ada studi pustaka yang membahas mengenai potensi Sovateltide sebagai obat neuroprotektif stroke iskemik. Oleh karena itu, penulis melakukan studi pustaka ini untuk mengetahui potensi Sovateltide sebagai obat neuroprotektif yang mutakhir dari stroke iskemik.

\section{METODE}

Studi pustaka ini dibuat secara sistematis menggunakan tahapan seperti pada gambar terlampir. Penulis menggunakan beberapa kata kunci berupa ETBR Agonist, Endothelin B Receptor Agonist, ET(B) Receptor Agonist, IRL-1620, PMZ-1620, Sovateltide, Ischemic Stroke, Infarct Stroke, Cerebral Ischemia yang diketik pada mesin pencarian Pubmed dan Google Scholar untuk mendapatkan jurnal. Kriteria inklusi adalah jurnal full text berbahasa Inggris dalam 10 tahun terakhir yang relevan dengan topik dan merupakan original research dengan sampel tikus. Penulis mendapatkan lima jurnal sebagai hasil utama. Kemudian, penulis menganalisis dan membuat studi pustaka berdasarkan jurnal-jurnal tersebut.

\section{HASIL DAN PEMBAHASAN}

\section{Patogenesis Stroke Iskemik}

Stroke iskemik disebabkan oleh tromboembolus yang menghalangi suplai $\mathrm{O}_{2}$ dan glukosa ke sel saraf dan glia untuk tersumbat menyebabkan sel saraf dan glia kekurangan $\mathrm{O}_{2}$ yang memicu depolarisasi progresif sehingga membentuk energi. $\mathrm{CBF}$ yang tersumbat menyebabkan sel saraf dan glia kekurangan $\mathrm{O}_{2}$ yang memicu depolarisasi progresif sehingga pelepasan glutamat meningkat. Glutamat mengaktivasi reseptor N-methyl-Daspartate (NMDA) sehingga $\mathrm{Ca}^{2+}$ masuk ke dalam sel. $\mathrm{Ca}^{2+}$ intrasel mengaktivasi neuronal nitric oxide synthase (nNOS) yang menghasilkan NO dan radikal bebas. NO membuat disfungsi mitokondria sehingga memicu rangkaian kematian sel. Selain itu, sel glia juga mengalami kerusakan karena tingginya $\mathrm{Ca}^{2+}$ intrasel, contohnya astrosit yang akan menjadi reaktif.

Pada stroke iskemik, kadar ET akan meningkat. ET akan berikatan pada ETAR dan ETBR. Pengikatan ET dengan ETAR pada otot polos vaskular memicu kontraksi dan meningkatkan stres oksidatif. ET dapat mengaktivasi produksi superoxide melalui $N A D(P) H$ oxidase yang akan meningkatkan permeabilitas Blood Brain Barrier (BBB) dan menyebabkan edema. Rusaknya BBB menyebabkan inflamasi yang dapat merusak neuron. Namun, pengikatan ET dengan ETBR memberikan efek protektif.

\section{Struktur dan Biosintesis Endotelin}

ET merupakan suatu peptide endogen yang berdasarkan strukturnya terdiri atas tiga jenis, yaitu ET-1, ET-2, dan ET-3. Transkripsi dan translasi dari endothelin-1 precursor gene menghasilkan prekursor 
ET, preproETs, yang tersusun atas 200 residu asam amino. PreproETs kemudian ditransfer ke retikulum endoplasma untuk dipecah oleh furin- like endopeptidase sehingga menghasilkan 37-41 peptida asam amino intermediat inaktif atau disebut juga big ETs. Big ETs kemudian dipecah lagi menjadi 21 asam amino yang sudah matang oleh endothelin-converting enzymes (ECEs) sehingga menghasilkan ET-1 yang aktif ECEs diekspresikan oleh sel endotelium, glia, dan saraf.

\section{Reseptor Endotelin}

Endotelin memiliki dua $G$ - protein coupled receptors (GPCR), yaitu ETAR dan ETBR. Pada sistem vaskular, ETAR dan ETBR terdapat pada otot polos pembuluh darah. Selain itu, ETBR juga terdapat pada sel endotelium. ET-1 dan ET2 berikatan dengan afinitas yang sama besar dengan kedua reseptor tersebut. Namun, ET-3 cenderung mengikat ETBR. Reseptor endotelin juga terdapat pada sel saraf, astrosit, dan sel endotelium di otak. Secara spesifik, ETAR lebih banyak terdapat pada sel saraf, sedangkan ETBR pada sel glia. Secara keseluruhan, di otak, terdapat lebih banyak ETBR daripada ETAR.

Stimulasi ETAR dan ETBR menghasilkan efek yang berlawanan. Stimulasi ETAR memediasi vasokonstriksi, sedangkan stimulasi ETBR akan menyebabkan vasodilatasi. Saat ini, terdapat beberapa agonis ETBR yang selektif, yakni sarafotoxin $6 c$, BQ3020, dan Sovateltide. Dari berbagai agonis ETBR tersebut, Sovateltide merupakan yang paling selektif.

\section{Efek Neuroprotektif Sovateltide}

Stimulasi ETBR pada otak telah diketahui memberikan banyak efek neuroprotektif, yakni meningkatkan proliferasi, survival rate, diferensiasi, neurogenesis, fusion mitokondria, dan perkembangan sel saraf. Penelitian menunjukkan bahwa pemberian antagonis ETBR, BQ788, sebelum pemberian agonis ETBR, memberikan efek yang hampir sama dengan pemberian larutan salin normal pada tikus dengan MCAO. Hal ini menunjukkan bahwa efek neuroprotektif tersebut secara spesifik dihasilkan oleh stimulasi ETBR.

Berdasarkan penelitian, survival rate pada tikus dengan MCAO yang diberikan Sovateltide lebih tinggi daripada yang hanya diberikan larutan salin normal. Tikus dengan MCAO yang diberikan Sovateltide merupakan kelompok sampel yang paling banyak dapat bertahan hidup sampai hari ke-7. Hal ini membuktikan bahwa Sovateltide memiliki potensi untuk pengobatan stroke iskemik akut maupun subakut.

Pemberian Sovateltide juga menunjukkan penurunan defisit neurologis dan peningkatan fungsi motoric pada tikus tersebut. Seluruh hasil pada lima jurnal utama studi pustaka ini melaporkan bahwa pada hari ke-7, tikus dengan MCAO yang diberikan Sovateltide memiliki fungsi neurologis dan motorik yang paling baik dibandingkan dengan kelompok kontrol dan kelompok tikus yang diberikan larutan salin normal. Kemampuan motorik diuji dengan pemeriksaan grip, rota rod, foot faut, dan aktivitas lokomotor.

Tingkat stres oksidatif dapat diukur dengan kadar malondialdehyde (MDA), sedangkan tingkat antioksidan dapat diukur dengan reduced glutathione (GSH) dan superoxide dismutase (SOD). Pada tikus dengan MCAO yang diberikan Sovateltide, 
terjadi penurunan stres oksidatif yang ditandai dengan penurunan kadar MDA sekitar 70-80\%. Di lain sisi, GSH dan SOD meningkat.

Selain itu, stimulasi ETBR juga mengurangi permeabilitas gap junction, menghambat terjadinya edema, dan mengurangi reaksi inflamasi pada fase subakut stroke iskemik. Oleh karena itu, stres oksidatif yang dihasilkan pun berkurang.

Stres oksidatif dapat menstimulasi perubahan astrosit menjadi astrosit reaktif. Astrosit reaktif dapat menstimulasi proinflammatory cytokines sehingga membahayakan sel-sel saraf. Pada tikus dengan MCAO yang diberikan Sovateltide, terjadi penurunan stres oksidatif. Oleh karena itu, pemberian Sovateltide dapat menurunkan jumlah astrosit reaktif.

Doublecortin (DCX) merupakan markah untuk menghitung jumlah NPCs. Pada jaringan otak tikus dengan MCAO, kadar DCX menurun secara signifikan. Pemberian Sovateltide pada tikus dengan MCAO menunjukkan kadar DCX yang lebih tinggi secara signifikan daripada yang hanya diberikan larutan salin normal. Oleh karena itu, Sovateltide mampu menyelamatkan NPCs saat terjadi iskemia akut pada jaringan otak.

Embryonic lethal, abnormal vision (ELAV) family proteins, seperti $\mathrm{HuC}$ dan $\mathrm{HuD}$, merupakan protein pengatur diferensiasi dan maturase NPCs. Oleh karena itu, peningkatan NPCs setelah pemberian Sovateltide pada tikus dengan MCAO juga menyebabkan peningkatan ekspresi HuC dan HuD.

Protein $\mathrm{HuD}$ memiliki mekanisme positive feedback loop terhadap faktor transkripsi, SA TB1, yang dapat berikatan dengan DNA dan kemudian meningkatkan ekspresi markah diferensiasi saraf, yaitu NeuroD1, dan markah saraf yang sudah matang, yaitu NeuN (Gambar 1). Pemberian Sovateltide pada jaringan otak tikus dengan MCAO menunjukkan kadar NeuroD1 dan NeuN yang lebih tinggi daripada yang hanya diberikan larutan salin normal. Hal ini menunjukkan Sovateltide mampu mempercepat diferensiasi NPCs menjadi sel saraf yang matang dalam proses regenerasi saraf setelah terjadinya stroke iskemik.

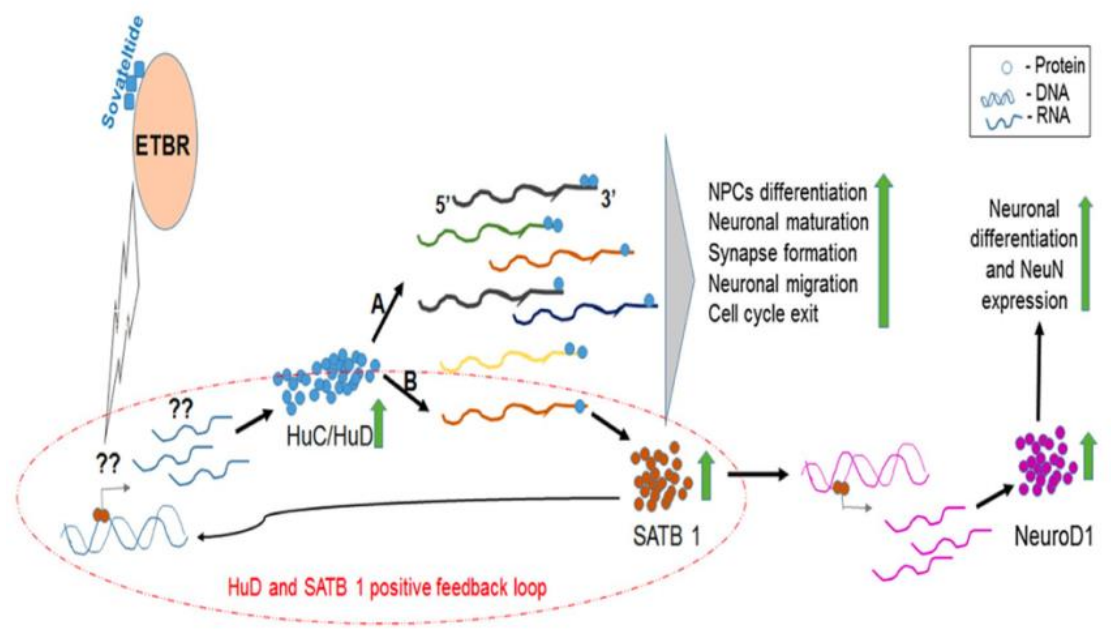

Gambar 1. Mekanisme Sovateltide dalam meningkatkan diferensiasi sel-sel saraf. 
Regenerasisuatu organ yang mengalami kerusakan dapat diamati dengan melihat fusion, fission, dan biogenesis mitokondria sel. Fission mitokondria berhubungan dengan disfungsi sel, sedangkan fusion mitokondria berhubungan dengan mitokondria yang sehat dan fungsional. Pemberian Sovateltide menunjukkan adanya peningkatan kadar markah fusion mitokondria, yaitu Mfn2, dan penurunan markah fission mitokondria, yaitu Drp1, pada jaringan otak tikus dengan MCAO. Selain itu, pengujian dengan Polymerase Chain Reaction (PCR) terhadap gen yang secara eksklusif terdapat pada DNA mitokondria, yaitu MT-A TP8, menunjukkan jumlah mitokondria yang lebih banyak pada jaringan otak tikus dengan MCAO yang diberikan Sovateltide daripada yang hanya diberikan larutan salin normal. Hal ini membuktikan bahwa Sovateltide meningkatkan kemampuan biogenesis mitokondria sel saraf.

Pemberian Sovateltide juga mampu meningkatkan Nerve Growth Factor (NGF) pada tikus dengan MCAO. NGF dianalisis dengan menggunakan western blotting yang kemudian dikonfirmasi dengan immunofluorescence. Setelah 24 jam, tikus dengan MCAO yang diberikan Sovateltide mengalami peningkatan NGF pada bagian hemisfer otak yang mengalami infark. Setelah satu minggu setelah MCAO, tikus yang diberikan Sovateltide mengalami peningkatan NGF lebih tinggi dibandingkan dengan kelompok kontrol. Jika dibandingkan dengan kelompok tikus yang diberikan larutan salin normal, kelompok tikus yang diberikan Sovateltide mengalami peningkatan NGF sedikit lebih tinggi. Hal ini mengindikasikan bahwa ETBR mampu bekerja sebagai target untuk perbaikan neurovaskularisasi pada sistem saraf pusat.

Tidak hanya itu, Sovateltide juga terbukti mampu meregulasi protein proapoptosis. Aktivasi PI3K / Akt telah banyak dilaporkan berperan dalam perlindungan terhadap iskemia otak. Berdasarkan penelitian, terjadi peningkatan transient pAkt pada tikus MCAO yang diberikan Sovateltide pada tahap awal iskemia. Selain itu, pada jam ke-7 setelah tikus mengalami MCAO, tikus yang diberikan Sovateltide mengalami penurunan Bad (proapoptosis) dibandingkan dengan kelompok tikus kontrol dan tikus MCAO yang diberikan larutan salin normal.

Protein regulator lain yang berperan dalam tahap awal apoptosis adalah Bcl-2 dan Bax, yang merupakan target dari Akt. Pemberian Sovateltide pada tikus MCAO menyebabkan peningkatan Bcl-2 dan penurunan Bax. Berbagai obat neuroprotektif mampu mengurangi dampak stroke iskemik melalui peningkatan ekspresi Bcl-2. Di lain sisi, Bax merupakan proapoptosis. Penemuan ini mengindikasikan bahwa Sovateltide mampu menghambat apoptosis dengan menghambat pengikatan Bax ke mitokondria. 


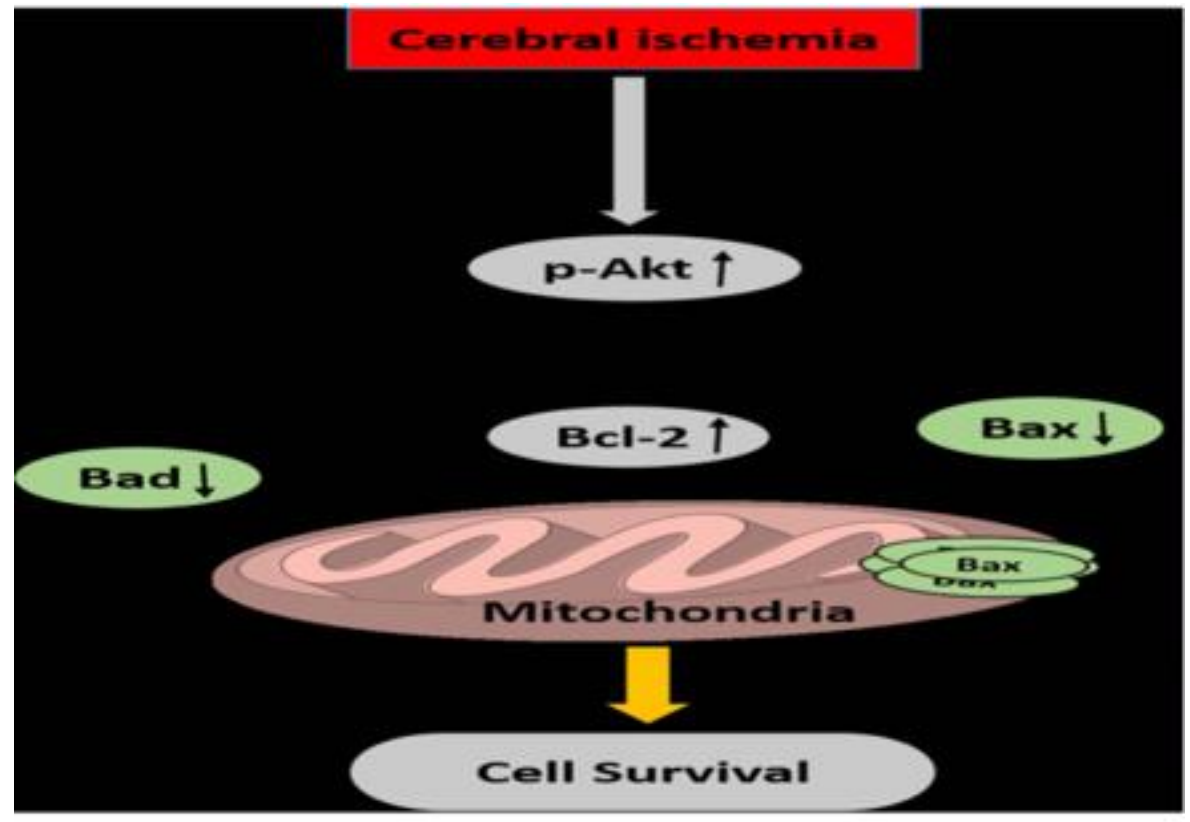

Gambar 2. Pemberian Sovateltide pada tikus dengan MCAO mampu menurunkan protein proapoptosis, yakni Bax dan Bad, dan meningkatkan antiapoptosis, yakni p- Akt dan Bcl-2.

\section{Efek Angiogenesis Sovateltide}

VEGF merupakan protein angiogenik yang terdiri atas VEGF- A, B, C, dan D. Peningkatan produksi VEGF-A pada jaringan otak terjadi karena hipoksia, peningkatan ekspresi platelet-activating factor, interleukin-6 (IL-6), dan IL-1 $\beta$. VEGF-A yang dihasilkan akan merangsang terjadinya angiogenesis

Penelitian membuktikan bahwa pemberian Sovateltide yang merupakan agonis ETBR selektif pada tikus dapat meningkatkan produksi VEGF-A di otak besar. Ketika teraktivasi, VEGF dapat menghambat apoptosis, menstimulasi neurogenesis dan angiogenesis, dan mengaktivasi antioksidan.

Penelitian membuktikan bahwa pemberian Sovateltide mampu meningkatkan jumlah VEGF sampai satu minggu setelah otak tikus mengalami MCAO dibandingkan dengan tikus dengan MCAO yang diberikan larutan salin normal.
Penelitian lain juga membuktikan bahwa pemberian Sovateltide dapat mengurangi volume otak yang mengalami infark. $\mathrm{CBF}$ di kedua hemisfer otak diperiksa dengan Laser Speckle Contrast Analysis. Hasilnya menunjukkan bahwa setelah hari ke-7 pemberian Sovateltide pada tikus dengan MCAO, CBF pada hemisfer otak yang mengalami infark membaik jika dibandingkan dengan kelompok tikus yang diberikan larutan salin normal. Selain itu, volume bagian otak yang mengalami infark juga menjadi lebih kecil. Hal ini terjadi pada tikus dewasa maupun anak-anak.

\section{KESIMPULAN DAN SARAN}

\section{Kesimpulan}

Stroke iskemik adalah gangguan neurologis yang disebabkan oleh tromboembolus di otak. Pada stroke iskemik, terjadi peningkatan ET yang tidak selektif. ET merupakan suatu peptida endogen vasoaktif yang memiliki dua GPCR, yakni ETAR dan ETBR. ETAR 
memediasi vasokonstriksi, sedangkan ETBR memediasi vasodilatasi. Peningkatan ET yang tidak selektif dapat menyebabkan kerusakan saraf pada stroke iskemik. Sebagai agonis ETBR paling selektif, Sovateltide sudah terbukti berpotensi sebagai obat neuroprotektif pada stroke iskemik fase akut dan subakut dengan cara merangsang regenerasi, menghambat kerusakan sel saraf, dan meningkatkan angiogenesis.

\section{Saran}

Tentunya, hal ini memicu perkembangan ilmu pengetahuan karena dibutuhkan uji klinis lebih lanjut pada manusia untuk mengoptimalisasi penggunaan obat ini. Perlu dilakukan juga penelitian lebih lanjut mengenai kontraindikasi, efek samping, dan window period penggunaan Sovateltide. Selain itu, pendekatan holistik melalui kerja sama dengan pemerintah dan sosialisasi kepada masyarakat sangat dibutuhkan agar obat ini dapat segera diterapkan kepada pasien mengingat morbiditas dan mortalitas yang ditimbulkan oleh stroke iskemik sangat tinggi.

\section{DAFTAR PUSTAKA}

1. Campbell BCV, De Silva DA, Macleod MR, Coutts SB, Schwamm LH, Davis SM, et al. Ischaemic stroke. Nat Rev Dis Prim [Internet]. 2019;5(1). Available from: http://dx.doi.org/10.1038/s415 72019-0118-8

2. Hankey GJ. Stroke. Lancet. 2017;389(10069):641-54.

3. Kemenkes R. Infodantin Stroke Kemenkes Ri 2019. Infodantin Stroke Kemenkes RI 2019. 2019.

4. Johnson W, Onuma O, Owolabi M, Sachdev S. Stroke: A global response is needed [Internet]. V ol. 94, Bulletin of the World Health Organization. World Health Organization; 2016 [cited 2020 Aug 3]. p. 634-635 Available http://www.who.int/bulletin/v olumes/94/9/16-181636/en/

5. Feigin VL, Norrving B, Mensah GA. Global Burden of Stroke. Circ Res. 2017;120(3):439-48.

6. V enketasubramanian $\mathrm{N}, \mathrm{Y}$ oon $\mathrm{BW}$, Pandian J, Navarro JC. Stroke epidemiology in south, east, and southeast asia: A review. J Stroke. 2017;19(3):286-94.

7. Abbott AL, Silvestrini M, Topakian R, Golledge J, Brunser AM, de Borst GJ, et al. Optimizing the definitions of stroke, transient ischemic attack, and infarction for research and application in clinical practice. Front Neurol. 2017;8(OCT):1-14.

8. Mutiarasari D. Ischemic Stroke: Symptoms, Risk Factors, and Prevention. Med Tadulako, J Ilm Kedokt. 2019;1(2):36-44.

9. Sacco RL, Kasner SE, Broderick JP , Caplan LR, Connors JJ, Culebras A, et al. An updated definition of stroke for the 21st century: A statement for healthcare professionals from the American heart association/American stroke association. Stroke 2013;44(7):2064-89.

10. deV eber GA, Kirton A, Booth FA, Yager JY, Wirrell EC, Wood E, et al. Epidemiology and Outcomes of Arterial Ischemic Stroke in Children: The Canadian Pediatric Ischemic Stroke Registry. Pediatr Neurol [Internet]. 2017;69:58-70. from: http://dx.doi.org/10.1016/j.ped iatrneurol.2017.01.016 
11. Felling RJ, Sun LR, Maxwell EC, Goldenberg N, Bernard T. Pediatric arterial ischemic stroke: Epidemiology, risk factors, and management. Blood Cells, Mol Dis [Internet]. 2017;67:23-33. Available from: http://dx.doi.org/10.1016/j.bc md.2017.03.003

12. Cifuentes EG, Hornick MG, Havalad S, Donovan RL, Gulati A. Neuroprotective effect of IRL-1620, an endothelin B receptor agonist, on a pediatric rat model of middle cerebral artery occlusion. Front Pediatr. 2018;6(October)

13. Antonios N, Silliman S. Treatment of Acute Ischemic Stroke. Stroke. 2013;37-54

14. Gulati A, Hornick MG, Briyal S, Lavhale MS. A novel neuroregenerative approach using ETB receptor agonist, IRL-1620, to treat CNS disorders. Physiol Res. 2018;67:S95-113.

15. Secades JJ, Alvarez-Sabín J, Castillo J, Díez-Tejedor E, Martínez-Vila E, Ríos $\mathrm{J}$, et al. Citicoline for Acute Ischemic Stroke: A Systematic Review and Formal Meta-analysis of Randomized, Double-Blind, and Placebo-Controlled Trials. J Stroke Cerebrovasc Dis [Internet]. 2016;25(8):1984- 96. Available from: http://dx.doi.org/10.1016/j.jstr okecerebrovasdis.2016.04.010

16. Meschia JF, Bushnell C, Boden-albala B, Braun LT, Dawn M, Chaturvedi S, et al. AHA / ASA Guideline. Stroke. 2014;45:3754-832.

17. Fonarow GC, Grau-Sepulveda M V ., Saver JL, Reeves MJ, Cox M, Schwamm LH, et al. Why are acute ischemic stroke patients not receiving
IV
tPA?
Neurology.
2016;87(15):1565-74.

18. Leonard MG, Briyal S, Gulati A. Endothelin B receptor agonist, IRL1620, provides long-term neuroprotection in cerebral ischemia in rats. Brain Res [Internet]. 2012;1464:14- 23. Available from: http://dx.doi.org/10.1016/j.bra inres.2012.05.005

19. Karsy M, Brock A, Guan J, Taussky P, Yashar M, Park MS. Neuroprotective strategies and the underlying molecular basis of cerebrovascular stroke. Neurosurg Focus. 2017;42(4):1-15.

20. National Birth Defects Prevention Month | CDC [Internet]. [cited $2020 \mathrm{Jul}$ 6]. Available from: https://www.cdc.gov/ncbddd/b irthdefects/prevention- month.html

21. Dávalos A, Alvarez-Sabín J, Castillo J, Díez-Tejedor E, Ferro J, Martínez-Vila $\mathrm{E}$, et al. Citicoline in the treatment of acute ischaemic stroke: An international, randomised, multicentre, placebo- controlled study (ICTUS trial). Lancet [Internet]. 2012;380(9839):349-57. Available from: http://dx.doi.org/10.1016/S01 40-6736(12)60813-7

22. Leonard MG, Briyal S, Gulati A. Endothelin B receptor agonist, IRL1620, reduces neurological damage following permanent middle cerebral artery occlusion in rats. Brain Res [Internet]. 2011;1420:48-58. Available from: http://dx.doi.org/10.1016/j.bra inres.2011.08.075

23. Briyal S, Shepard C, Gulati A. Endothelin receptor type B agonist, IRL-1620, prevents beta amyloid (A $\beta)$ induced oxidative stress and cognitive impairment in normal and diabetic rats. 
Pharmacol Biochem Behav [Internet]. 2014;120:65-72. Available from: http://dx.doi.org/10.1016/j.pbb .2014.02.008

24. Leonard MG, Gulati A. Endothelin B receptor agonist, IRL-1620, enhances angiogenesis and neurogenesis following cerebral ischemia in rats. Brain Res [Internet]. 2013;1528:2841. Available from: http://dx.doi.org/10.1016/j.bra inres.2013.07.002

25. Davenport AP, Hyndman KA, Dhaun N, Southan C, Kohan DE, Pollock JS, et al. Endothelin. Pharmacol Rev. 2016;95499.

26. Dhaun N, Webb DJ. Endothelins in cardiovascular biology and therapeutics. Nat Rev Cardiol [Internet]. 2019;16(8):491-502. Available from: http://dx.doi.org/10.1038/s415 69019-0176-3

27. Vignon-Zellweger $\mathrm{N}$, Heiden $\mathrm{S}$, Miyauchi T, Emoto N. Endothelin and endothelin receptors in the renal and cardiovascular systems. Life Sci [Internet]. 2012;91(13- 14):490-500. Available from: http://dx.doi.org/10.1016/j.lfs. 2012.03.026

28. Li W, Abdul Y, Ward R, Ergul A. Endothelin and diabetic complications: A brain-centric view. Physiol Res. 2018;67:S83-94.

29. Palmer JC, Barker R, Kehoe PG, Love $\mathrm{S}$. Endothelin-1 is Elevated in Alzheimer's Disease and Upregulated by Amyloid- $\beta$. J Alzheimer's Dis. 2012;29(4):853-61.

30. Briyal S, Gulati A. Endothelin- A receptor antagonist BQ123 potentiates acetaminophen induced hypothermia and reduces infarction following focal cerebral ischemia in rats. Eur $\mathbf{J}$ Pharmacol [Internet]. 2010;644(13):73-9. Available from:http://dx.doi.org/10.1016/j.ejp har.2010.06.071

31. D'Antoni S, Ranno E, Spatuzza M, Cavallaro S, Catania M V . Endothelin1 Induces Degeneration of Cultured Motor Neurons Through a Mechanism Mediated by Nitric Oxide and PI3K/Akt Pathway. Neurotox Res. 2017;32(1):58-70.

32. Hostenbach S, D'haeseleer M, Kooijman R, De Keyser J. The pathophysiological role of astrocytic endothelin-1. Prog Neurobiol [Internet]. 2016;144(2015):88-102. Available from: http://dx.doi.org/10.1016/j.pne urobio.2016.04.009

33. Laziz I, Larbi A, Grebert D, Sautel M, Congar $\mathrm{P}$, Lacroix MC, et al. Endothelin as a neuroprotective factor in the olfactory epithelium. Neuroscience [Internet]. 2011;172:209. Available from: http://dx.doi.org/10.1016/j.neuroscien ce.2010.10.063

34. Ranjan AK, Briyal S, Gulati A. Sovateltide ( IRL - 1620 ) activates neuronal differentiation and prevents mitochondrial dysfunction in adult mammalian brains following stroke. Sci Rep [Internet]. 2020;1-17. Avalaiable from: https://doi.org/10.1038/s41598 -02069673-w

35. Weilinger NL, Maslieieva V, Bialecki J, Sridharan SS, Tang PL, Thompson RJ. Ionotropic receptors and ion channels in ischemic neuronal death and dysfunction. Acta Pharmacol Sin [Internet]. 2013;34(1):39-48. 
Available

from:

http://dx.doi.org/10.1038/aps. 2012.95

36. Sun M, Jin H, Sun X, Huang S, Zhang $\mathrm{F}$, Guo Z. Free radical damage in ischemia reperfusion injury : An obstacle in acute ischemic stroke after revascularization therapy Acute ischemic stroke is a common cause of morbidity and mortality worldwide . thrombectomy are the main revascularization therapies. Oxid Med CellLongev. 2017;2018:1-17.

37. Ahrendsen JT, Grewal HS, Hickey SP, Culp CM, Gould EA, Shimizu T, et al. Juvenile striatal white matter is resistant to ischemia-induced damage. Glia. 2016;64(11):1972-86.

38. Hall CN, Reynell C, Gesslein B, Hamilton NB, Mishra A, Sutherland BA, et al. Capillary pericytes regulate cerebral blood flow in health and disease. Nature [Internet]. 2014;508(1):55-60. Available from: http://dx.doi.org/10.1038/natu re13165

39. Koyama $\mathrm{Y}$, Regulations of $\mathrm{P}$, functions by Roles in Michinaga S. astrocytic endothelins: the pathophysiological responses of damaged brains. J Pharmacol Sci. 2012;118(4):401-7.

40. Aslan O, Gurger M, Atescelik M, Kara M, Sen A, Alatas OD, et al. Endothelin-1 Lys198Asn and rs 10478694 polymorphism in ischemic stroke. Biomed Res. 2017;28(2):7504.

41. Coucha M, Li W, Ergul A. The effect of endothelin receptor A antagonism on basilar artery endotheliumdependent relaxation after ischemic stroke. Life Sci [Internet]. 2012;91(1314):676-80. Available from: http://dx.doi.org/10.1016/j.lfs.

2012.01.020
42. Palomares SM, J. Cipolla M. Vascular Protection Following Cerebral Ischemia and Reperfusion. J Neurol Neurophysiol. 2011;01(01):1- 12.

43. Castañeda MM, Cubilla MA, LópezVicchi MM, Suburo AM. Endothelinergic cells in the subependymal region of mice. Brain Res [Internet]. 2010;1321:20-30. Available from: http://dx.doi.org/10.1016/j.bra inres.2010.01.056

44. Gulati A. Endothelin Receptors, Mitochondria and Neurogenesis in Cerebral Ischemia. Curr Neuropharmacol. 2016;14(6):619-26.

45. Leonard MG, Prazad P Puppala B, Gulati A. Selective Endothelin-B Receptor Stimulation Increases Vascular Endothelial Growth Factor in the Rat Brain during Postnatal Development. Drug Res (Stuttg). 2015;65(11):607-13.

46. Ranjan AK, Briyal S, Khandekar D, Gulati A. Sovateltide (IRL-1620) affects neuronal progenitors and prevents cerebral tissue damage after ischemic stroke. Can J Physiol Pharmacol. 2020;1-28.

47. Briyal S, Ranjan AK, Hornick MG, Puppala AK, Luu T, Gulati A. Antiapoptotic activity of ETB receptor agonist, IRL-1620, protects neural cells in rats with 2019;9(1):1-13.

48. Zhang J, Jiao J. Molecular Biomarkers for Embryonic and Adult Neural Stem Cell and Neurogenesis. Biomed Res Int. 2015;2015.

49. Baser A, Skabkin M, Kleber S, Dang Y, Gülcüler Balta GS, Kalamakis G, et al. Onset of differentiation is posttranscriptionally controlled in adult neural stem cells.Nature. 2019;566(7742):100-4. 
50. Fallini C, Zhang H, Su Y, Silani V, Singer RH, Rossoll W, et al. The Survival of Motor Neuron (SMN) protein interacts with the mRNAbinding protein $\mathrm{HuD}$ and regulates localization of poly(A) mRNA in primary motor neuron axons. J Neurosci. 2011;31(10):3914- 25.

51. Wang F, Tidei JJ, Polich ED, Gao Y, Zhao H, Perrone- Bizzozero NI, et al. Positive feedback between RNAbinding protein $\mathrm{HuD}$ and transcription factor SA TB1 promotes neurogenesis. Proc NatlAcadSciUSA. 2015;112(36):E4995-5004.

52. Koyama Y, Nagae R, Tokuyama S, Tanaka K. I.c.v administration of an endothelin ETB receptor agonist stimulates vascular endothelial growth factor-A production and activates vascular endothelial growth factor receptors in rat brain. Neuroscience [Internet]. 2011;192:689-98. Available from: http://dx.doi.org/10.1016/j.neu roscience.2011.05.058 